Keywords:

Micropropagation

Tissue culture

Forestry species

Histórico:

Recebido 20/12/2016

Aceito 05/04/2017

Palavras chave:

Micropropagação

Cultura de tecidos

Espécie florestal

${ }^{+}$Correspondência: liarsr@ufsm.br

DOI:
Silvia Machado dos Santos Rabaiolli', Lia Rejane Silveira Reiniger ${ }^{l+}$, Charlene Moro Stefanel', Karol Buuron da Silva', Aline Ferreira Paim', Ana Cristina da Fonseca Ziegler'

\section{AGAR DOES NOT AFFECT IN VITRO RHIZOGENESIS AND EX VITRO ACCLIMATIZATION OF Handroanthus chrysotrichus}

ABSTRACT: The golden trumpet tree Handroanthus chrysotrichus (Bignoniaceae) is an important species, owing to its economic, ecological, medicinal, and ornamental value. However, its production is hindered due to lack of seed availability and viability improved methods of vegetative propagation are needed. Therefore, we evaluated the effect of agar on in vitro rhizogenesis of $H$. chrysotrichus shoots and the subsequent ex vitro acclimatization of the plants obtained. In the in vitro rhizogenesis assay, we cultured the micropropagated shoots on half-strength nutritive Woody Plant Medium (1/2WPM) supplemented with $30 \mathrm{~g} \cdot \mathrm{L}^{-1}$ sucrose, $50 \mathrm{mg} \cdot \mathrm{L}^{-1}$ myoinositol, $30 \mathrm{~cm}^{3}$ of vermiculite, and one of the three agar concentrations $(0$, 3.5 , or $\left.7 \mathrm{~g} \cdot \mathrm{L}^{-1}\right)$, and after $30 \mathrm{~d}$, we assessed the shoots for root production and leaf number. Thereafter, the plants were subjected to a 49-d ex vitro acclimatization period, which consisted of two stages in a growth room and one stage in a greenhouse; we assessed plant survival, leaf number and increases in stem height at the end of each stage. We found that the addition of agar to the growth medium was not necessary to induce adventitious rooting, especially with respect to secondary roots, and that plants grown on medium without agar had the highest number of leaves after acclimatization. Therefore, agar actually hindered both in vitro rhizogenesis and ex vitro acclimatization. The ex vitro acclimatization result in high survival and resumption of growth and development of $\mathrm{H}$. chrysotrichus micropropagated plants, and this step is not affected by agar on in vitro rhizogenesis.

\section{AGAR NÃO AFETA A RIZOGÊNESE IN VITRO E A ACLIMATIZAÇÃO EX VITRO DE Handroanthus chrysotrichus}

RESUMO: Handroanthus chrysotrichus (Mart. ex DC.) J. Mattos (Bignoniaceae), conhecida como ipê-amarelo, é uma espécie dotada de importância econômica, ecológica e ornamental. No presente trabalho o objetivo foi avaliar o efeito do ágar na rizogênese in vitro e na subsequente aclimatização ex vitro, bem como a eficiência deste processo em relação à sobrevivência e à retomada do crescimento e desenvolvimento das plantas micropropagadas de $H$. chrysotrichus. Na rizogênese in vitro, brotações micropropagadas na ausência de reguladores de crescimento foram cultivadas in vitro por 30 dias, em meio nutritivo WPM cujas concentrações de sais foram reduzidas à metade (1/2WPM), acrescido de $30 \mathrm{~g} \cdot \mathrm{L}^{-1}$ de sacarose, $50 \mathrm{mg} \cdot \mathrm{L}^{-1}$ de mio-inositol e $30 \mathrm{~cm}^{3}$ de vermiculita, na presença de diferentes concentrações de ágar ( 0 ; 3,5 ou $\left.7 \mathrm{~g} \cdot \mathrm{L}^{-1}\right)$ e ausência de fitorreguladores. Decorrido esse período, as plantas provenientes dos tratamentos do ensaio de rizogênese foram submetidas à aclimatização ex vitro, processo composto por três etapas e duração de 49 dias. $O$ ágar foi dispensável na indução de raízes adventícias, principalmente no que diz respeito às secundárias. Igualmente, na aclimatização, plantas provenientes de cultivo na ausência de ágar apresentaram melhor desempenho, em especial no que diz respeito ao número de folhas. $A$ ausência de ágar propicia elevadas médias de rizogênese, e, simultaneamente, plantas com características adequadas para iniciar a aclimatização. A aclimatização resulta em elevada sobrevivência, retomada do crescimento e desenvolvimento de plantas micropropagadas de H. chrysotrichus, e esta etapa também não é afetado pelo ágar na etapa de rizogênese.

Federal University of Santa Maria - Santa Maria, Rio Grande do Sul, Brazil 


\section{INTRODUCTION}

The golden trumpet tree, Handroanthus chrysotrichus (Mart. ex DC.) J. Mattos (Bignoniaceae) is a deciduous species that is typical of open formations in the rainforest of the Atlantic slope (LORENZI, 2008) and is important, owing to its economic, ecological, ornamental and medicinal value (OLIVEIRA et al., 2008). However, despite the fact that congeneric species produce high quantities of seeds (LORENZI, 2008), the production of seeds in $H$. chrysotrichus is inconsistent (SOUZA et al., 20I5), and studies suggest that the germination rate and viability of the seeds are reduced upon storage (OLIVEIRA et al., 2005). Therefore, the development of vegetative propagation methods for plant production is imperative.

One such method, micropropagation, is one of the most relevant methodologies in vegetative propagation, since it requires less physical space and does not depend on climatic conditions. In the genetic breeding of tree species in particular, micropropagation can be utilized in the in vitro conservation of germplasm, acceleration of genetic improvement programs, multiplication of superior clones for seedling production, rejuvenation of clones that have been selected at the mature phase, and various other processes (XAVIER et al., 20I3).

Since the formation of secondary roots is often a limiting factor for the in vitro culture of woody species, sometimes both auxins and modified nutritive media are necessary to achieve better results (CURTI; REINIGER, 2014). A previous study carried out by our research group demonstrated that auxins were not necessary for in vitro rhizogenesis of $H$. chrysotrichus (data not published). However, seedlings cultivated in media with agar often exhibit weak radicular systems that lack root hairs (ROCHA et al., 2006; SADEGHI et al., 20I5), which results in a low survival rate after the plants are moved to a greenhouse (XAVIER et al., 20I3); in addition, agar is among the most expensive of the nutritive medium ingredients (SUTHAR et al., 20I I; SILVA et al., 20l4). Moreover, it is necessary to develop alternatives to reduce production costs in the plant tissue culture (SCHEIDT et al., 20I I).

Therefore, the agar is the most-commonly used gelling agent for in vitro rhizogenesis. Alternative substrates have also been used, in order to enhance both root development and the subsequent acclimatization of the plants in greenhouse conditions (ROCHA et al., 2006; VIEIRA et al., 2007; CASANOVA et al., 2008; DAMIANI; SCHUCH, 2009; KAÇAR et al., 20I0; AGGARWAL; NIRMALA, 20I2; GALDIANO JUNIOR et al., 20I2), and might be useful for promoting in vitro rhizogenesis of $H$. chrysotrichus. In order to achieve better results, liquid medium-soaked vermiculite, perlite, and polyurethane sponges represent promising alternatives to agar and are also less expensive (BRAGA et al., 20I I).

In addition, the acclimatization of micropropagated plants is another barrier to in vitro culture, since the transfer of seedlings from a protected environment to a natural environment with lower humidity can result in seedling death or in decreased growth that prolongs the period required for the plants to adapt completely (ANTONIAZZI et al., 20 I 3). Therefore, root formation must be considered in the acclimatization and hardening-off periods, which are the last stages of the propagation process, so that the survival and development of micropropagated plants can be improved. It is likely that nutritive media with vermiculite would facilitate the acclimatization process, owing to an increased area of contact between roots and the substrate, which would improve the absorption of water and nutrients (BRAGA et al., 20l I).

Thus, the objective of the present study was to evaluate the effect of agar on in vitro rhizogenesis of $H$. chrysotrichus shoots and the subsequent ex vitro acclimatization of the resulting plants.

\section{MATERIAL AND METHODS}

\section{Effect of agar on in vitro rhizogenesis}

$H$. chrysotrichus shoots were isolated from seedlings germinated in vitro on half-strength Woody Plant Medium (1/2WPM; LLOYD; McCOWN, 198I) and were subsequently cultivated in vitro for $30 \mathrm{~d}$ in full-strength WPM that was supplemented with $30 \mathrm{~g} \cdot \mathrm{L}^{-1}$ sucrose, $100 \mathrm{mg} \cdot \mathrm{L}^{-1}$ myo-inositol, and $7 \mathrm{~g} \cdot \mathrm{L}^{-1}$ agar, in the absence of growth regulators. After this, the explants were transferred to I50-mL glass flasks (3 explants per flask) that contained $30 \mathrm{~mL} 1 / 2 \mathrm{WPM}$ supplemented with $30 \mathrm{~g} \cdot \mathrm{L}^{-1}$ sucrose, $50 \mathrm{mg} \cdot \mathrm{L}^{-1}$ myo-inositol, $30 \mathrm{~cm}^{3}$ vermiculite, and the appropriate amount of agar. The treatments consisted of different agar concentrations $\left(0,3.5\right.$, or $\left.7.0 \mathrm{~g} \cdot \mathrm{L}^{-1}\right)$ in the nutritive medium, and the explants were assigned to one of the three treatments using a completely randomized design, with eight replicates for each treatment and 72 explants in total.

When preparing the $1 / 2$ WPM flasks, the $\mathrm{pH}$ of the medium was adjusted to 5.8 before adding the agar (i.e. $0,3.5$, or $7.0 \mathrm{~g} \cdot \mathrm{L}^{-1}$ ), and the nutritive media were autoclaved at $121{ }^{\circ} \mathrm{C}$ and I atm pressure for $15 \mathrm{~min}$. Then, after adding the explants, the flasks were sealed with aluminum foil and kept in a growth room at 25 $\pm 3{ }^{\circ} \mathrm{C}$ for $30 \mathrm{~d}$, under a photoperiod of $16 \mathrm{~h}$ and 20 
$\mu \mathrm{mol} \mathrm{m} \mathrm{m}^{-2} \cdot \mathrm{s}^{-1}$ light intensity from white fluorescent lamps. Afterward, we calculated the percentages of explants with primary roots, and explants with secondary roots, as well as the number of leaves and mean root length $(\mathrm{cm})$ per explant.

\section{Effect of agar on the ex vitro acclimatization of micropropagated plants}

After $30 \mathrm{~d}$ of in vitro culture, plants from the previous assay were subject to ex vitro acclimatization. After washing the roots with distilled and autoclaved water to remove the nutritive medium, the plants were transferred to $300-\mathrm{mL}$ transparent plastic cups, each of which was filled with $250 \mathrm{~cm}^{3}$ substrate [l:I (v:v), mixture of vermiculite and a commercial substrate that included pine bark, soil acidity corrective, and mineral fertilizers] and had holes at the bottom. In addition, each of the plastic cups were covered with another $300-\mathrm{mL}$ cup that also had holes at the bottom, in order to promote a humid microenvironment and to allow gas exchange, as is required for acclimatization. Each of the cups contained an individual plant with a well-developed root, and at least 10 plants from each treatment (i.e. $0,3.5$, or $7.0 \mathrm{~g} \cdot \mathrm{L}^{-1}$ agar) were included ( $n=42$ ), using a completely randomized design. Finally, the cups were distributed on plastic trays that were filled to $10 \mathrm{~mL}$ with distilled water and then kept in a growth room under the same conditions used for in vitro rhizogenesis. The humidity inside the cups was checked daily, and water $(10 \mathrm{~mL})$ was added in order to maintain the hydric turgor of the plants, just if necessary.

Acclimatization of the plants was also evaluated at three different time points. The first ex vitro acclimatization stage consisted of $7 \mathrm{~d}$ in the growth room, after which the covers were removed and the plants were immediately evaluated for survival (plants with a green coloration), number of leaves per plant and height increase (cm). The second ex vitro acclimatization stage consisted of an additional $14 \mathrm{~d}$ in the growth room (total of $2 \mathrm{l} \mathrm{d}$ ), with uncovered cups, after which the same variables were analyzed. Immediately afterward, at $21 \mathrm{~d}$ from the start of the acclimatization process, the plants were repotted in I-L pots that were entirely filled with the same substrate used in the plastic cups. Then the third acclimatization stage was initiated by transferring the pots to a greenhouse, where the pots were randomly arranged on greenhouse benches. After $28 \mathrm{~d}$, the third evaluation was performed by analyzing the same set of variables.

\section{Statistical analyses}

After testing the normality of errors (KolmogorovSmirnov test) and the homogeneity of variances (Bartlett test), we transformed the averages, whenever necessary, using the $\sqrt{x+0.5}$ function, where $x$ represented the observed value. Analyses of variance were performed, and, when the F value was significant, a Tukey's test was performed, using a $5 \%$ significance level. The analyses were conducted using SISVAR (System for Analysis of Variance) for Windows, version 4.0 (FERREIRA, 20I I). In order to determinate the precision of the experiments, the index of variation (IV) was estimated as the coefficient of variation (CV) divided by the square root of the number of replicates (CARGNELUTTI FILHO et al., 20I4).

\section{RESULTS}

\section{Effect of agar on in vitro rhizogenesis}

The addition of agar to the nutritive medium had a significant effect on the in vitro formation of primary $(p=$ 0.0067 ; IV $=1 \mathrm{I} .98 \%)$ and secondary roots ( $\mathrm{p}=0.0089$; IV = 8.75\%; Table I). The absence and intermediate concentration of agar yielded the best results for the formation of primary roots and were statistically similar (Table I, Figure IA and B), whereas the standard agar concentration (7 g.L.-1, Table I, Figure IC) yielded significantly lower rates of primary root production.

Meanwhile, the highest mean rate of secondary root production occurred in the absence of agar (Table I, Figure IA), whereas the mean rates of the media with 3.5 and $7.0 \mathrm{~g} \cdot \mathrm{L}^{-1}$ agar were significantly lower and similar. In contrast to the influence of agar on the rhizogenesis of the shoots, we found that neither the number of leaves per shoot ( $p=0.1313$; IV $=13.20 \%)$ nor the root average length ( $p=0.1147$; IV = 60.10\%) were significantly affected and exhibited satisfactory mean values of 7.89 and $2.13 \mathrm{~cm}$, respectively.

\section{Effect of agar on the ex vitro acclimatization of micropropagated plants}

During the first acclimatization stage the survival rate $(p=0.3000 ; I V=9.49 \%)$, number of leaves $(p=$ 0.3813 ; IV = 9.38\%), and plant height increase ( $p=$ 0.6773 ; IV $=13.29 \%$ ) were not significantly affected by the addition of agar to the in vitro nutritive medium, and the plants exhibited $100 \%$ survival, a mean of 7.55 leaves, and a mean height increase of $3.29 \mathrm{~cm}$.

During the second acclimatization stage, we found that the survival rate ( $p=0.0007$; IV = II.92\%) and number of leaves ( $p=0.0010 ; \mathrm{IV}=1 \mathrm{I} .73 \%$ ) were significantly affected by the addition of agar to the in vitro nutritive medium (Table 2). Both survival rate and number of leaves were high under all treatments, especially in those without agar or with the intermediated concentration, for which the mean values were similar (Table 2, Figure 2B and C). 


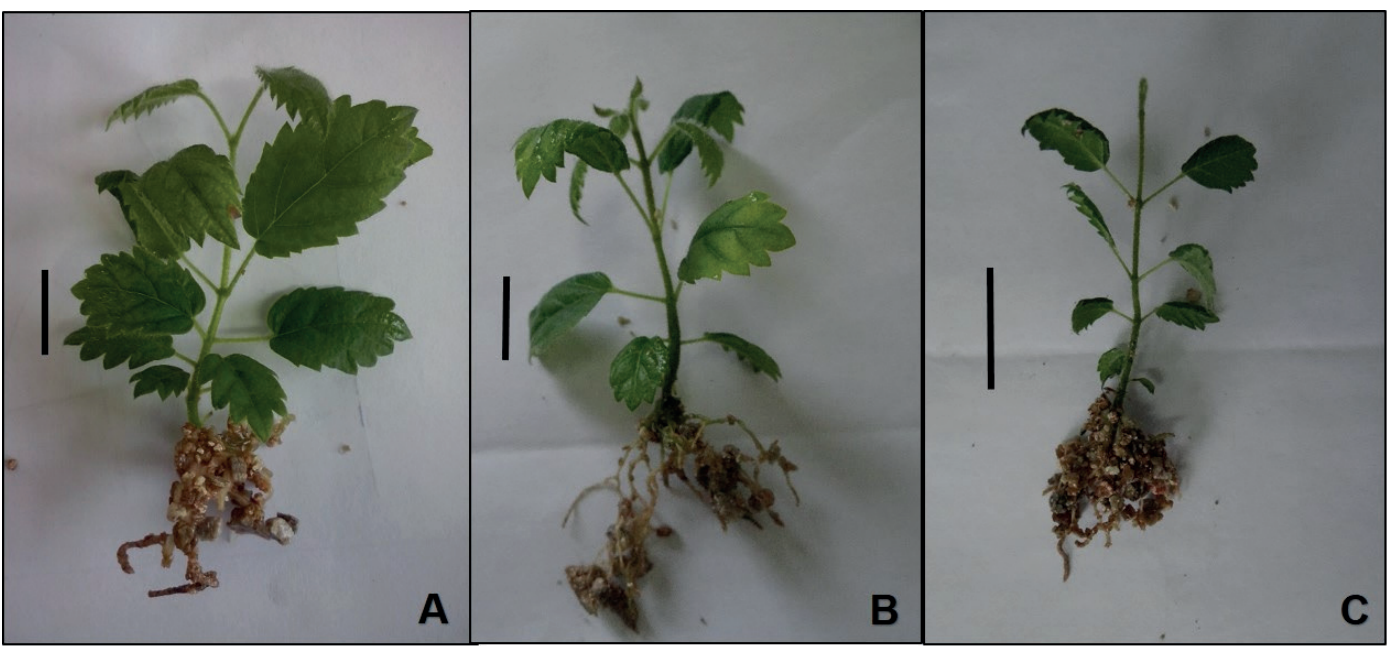

FIGURE I In vitro rhizogenesis of Handroanthus chrysotrichus shoots, after $30 \mathrm{~d}$ of culture in half-strength woody plant medium ( $1 / 2$ WPM) supplemented with $30 \mathrm{~cm} 3$ vermiculite and C) $7 \mathrm{~g} \cdot \mathrm{L}^{-1}$ agar, A) $3.5 \mathrm{~g} \cdot \mathrm{L}^{-1}$ agar, or B) $0 \mathrm{~g} \cdot \mathrm{L}^{-1}$ agar. Bar $=1 \mathrm{~cm}$.

TABLE I In vitro formation of primary and secondary roots of Handroanthus chrysotrichus shoots grown in half-strength woody plant medium ( $1 / 2$ WPM) supplemented with $30 \mathrm{~cm}^{3}$ vermiculite and various agar concentrations, after 30 days of in vitro culture.

\begin{tabular}{ccc}
\hline Treatments & $\begin{array}{c}\text { Primary } \\
\text { Roots } \\
(\%)\end{array}$ & $\begin{array}{c}\text { Secondary } \\
\text { Roots } \\
(\%)\end{array}$ \\
\hline $1 / 2 \mathrm{WPM}+$ vermiculite + agar $\left(7 \mathrm{~g} \cdot \mathrm{L}^{-1}\right)$ & $69.23 \mathrm{~b} *$ & $38.89 \mathrm{~b}$ \\
$1 / 2 \mathrm{WPM}+$ vermiculite + agar $\left(3.5 \mathrm{~g} \cdot \mathrm{L}^{-1}\right)$ & $94.44 \mathrm{a}$ & $30.77 \mathrm{~b}$ \\
$1 / 2 \mathrm{WPM}+$ vermiculite & $100.00 \mathrm{a}$ & $84.61 \mathrm{a}$ \\
\hline Average (\%) & 88.64 & 50.00 \\
$\mathrm{IV}(\%) * *$ & 11.98 & 8.75 \\
\hline
\end{tabular}

*Within each column, mean values followed by different lowercase letters differ significantly, according to Tukey's test at a 5\% significance level. **IV (index of variation), in which $\mathrm{CV}=$ coefficient of variation and $\mathrm{N}=$ number of replicates.

TABLE 2 Survival and number of leaves of micropropagated Handroanthus chrysotrichus plants after $21 \mathrm{~d}$ of ex vitro acclimatization in a growth room.

\begin{tabular}{ccc}
\hline Treatment* & $\begin{array}{c}\text { Survival rate } \\
(\%)\end{array}$ & Leaf number \\
\hline $1 / 2 \mathrm{WPM}+$ vermiculite + agar $\left(7 \mathrm{~g} \cdot \mathrm{L}^{-1}\right)$ & $72.22 \mathrm{~b} * *$ & $5.83 \mathrm{~b}$ \\
$1 / 2 \mathrm{WPM}+$ vermiculite $+\operatorname{agar}\left(3.5 \mathrm{~g} \cdot \mathrm{L}^{-1}\right)$ & $100.00 \mathrm{a}$ & $9.33 \mathrm{a}$ \\
$1 / 2 \mathrm{WPM}+$ vermiculite & $100.00 \mathrm{a}$ & $9.85 \mathrm{a}$ \\
Average (\%) & 87.50 & 7.92 \\
IV (\%)*** & 11.92 & 11.73
\end{tabular}

*Treatments indicate the conditions under which in vitro rhizogenesis of the explants were conducted. **Within each column, mean values followed by different lowercase letters differ significantly, according to Tukey's test at a $5 \%$ significance level. ***IV (index of variation), in which CV = coefficient of variation and $\mathrm{N}=$ number of replicates.

During the third acclimatization stage, we found that the survival rate $(p=0.3783$; IV $=9.82 \%)$ and plant height increase $(p=0.8568 ; \mathrm{IV}=15.25 \%)$ were not affected by the addition of agar to the in vitro nutritive medium, with mean values of $91.43 \%, 2.86 \%$, and 3.97 $\mathrm{cm}$, respectively. During this stage, only the number of leaves $(p=0.0346$; IV = 19.4\%) was significantly affected by agar, with plants cultured on medium without agar producing more leaves (13.08) than those cultured on media with intermediate or standard agar concentrations (8.3I and 8.89, respectively; Figure 2D, E, and F), as was observed at the end of the second acclimatization period.

\section{DISCUSSION}

\section{Effect of agar on in vitro rhizogenesis}

The absence and intermediate concentration of agar yielded the best results for the formation of primary roots, probably owing to higher substrate aeration and humidity. Meanwhile, for the formation of secondary roots, even half the standard agar concentration compromised shoot performance, which might indicate that the process requires more aeration and humidity than is necessary for the formation of primary roots. Similarly that was observed in our study in that the usual concentration also was the worst, Viaganó et al. (2007) demonstrated better in vitro rhizogenesis was achieved in Prunus cerasifera when MS medium (MURASHIGE; SKOOG, 1962) was supplemented with $200 \mathrm{~g} \cdot \mathrm{L}^{-1}$ vermiculite than with $7 \mathrm{~g} \cdot \mathrm{L}^{-1}$ agar, with an average rate of in vitro rhizogenesis above $90 \%$ after $35 \mathrm{~d}$ of culture. In Peltophorum dubium, Curti and Reiniger (2014) observed the highest rate of in vitro rhizogenesis (36.78\%) in shoots cultured on MS medium with both vermiculite and agar. Therefore, the use of a porous physical support, such as vermiculite imbibed with a nutritive solution, contributes to superior root formation, 


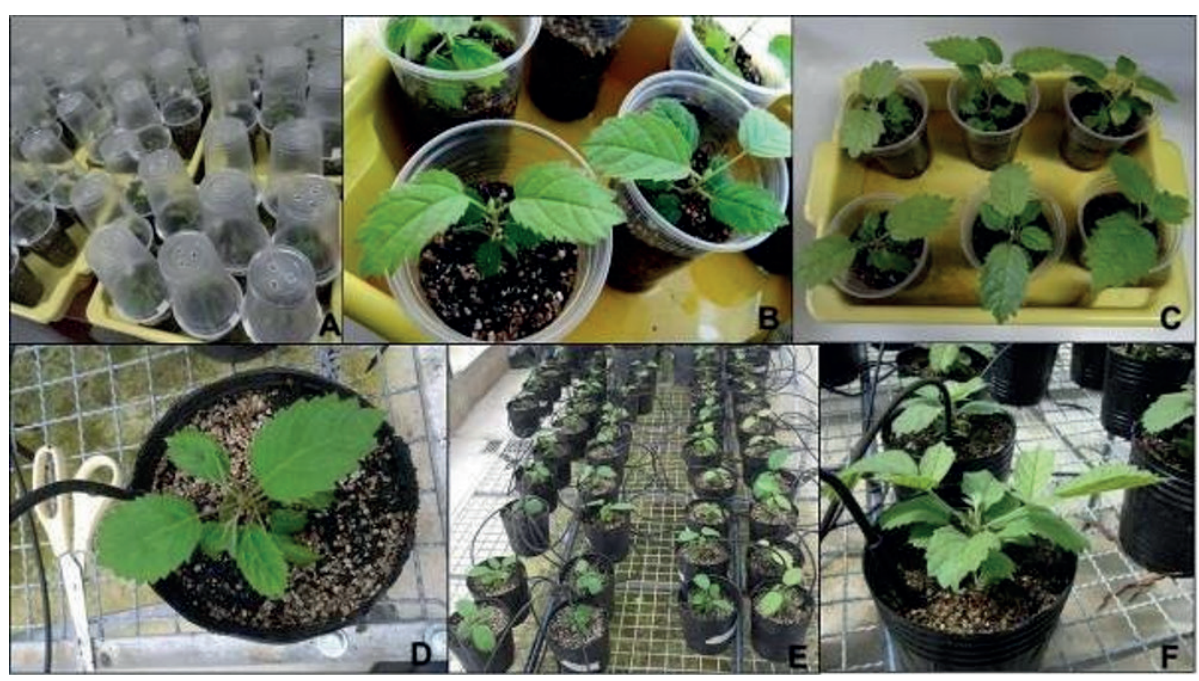

FIGURE 2 Forty-nine-day ex vitro acclimatization of micropropagated Handroanthus chrysotrichus. A) first stage (7 d in growth room); B) second stage ( $14 \mathrm{~d}$ in the growth room); C) plants at $21 \mathrm{~d}$, still in the growth room; D) plant at $21 \mathrm{~d}$, (after being repotted and moved to greenhouse); E) third stage ( $28 \mathrm{~d}$ in greenhouse); and F) plants at the completion of ex vitro acclimatization.

likely owing to greater aeration and water retention in the nutritive medium (CALDAS et al., 1990).

Although agar did not influence the formation of leaves, a satisfactory overall mean (7.89) was observed, probably because the nutritive medium provided the nutrients necessary to promote the observed growht. The presence of a specific number of leaves per shoot may stimulate rhizogenesis, as observed in our study, since leaves are a source of root promoting factors, such as auxins, cofactors, and photoassimilates (HARTMANN et al., 20I I).

In a previous study carried out by our research group, a lower mean root length $(0.92 \mathrm{~cm})$ was observed for $H$. chrysotrichus grown in $1 / 2$ WPM with vermiculite and auxin IBA (data not published), probably owing to the presence of this auxin, which is known to inhibit the elongation of roots. Rocha et al. (2006) indicated that the ideal average root length is between 2 and $3 \mathrm{~cm}$, since, depending on the flask diameter and number of cultivated explants, the roots may become entangled. Shorter roots would be better for plants being transplanted, since the removal of adhered culture medium would likely be easier and cause less damage to the roots. However, in the present study, we found that long roots failed to compromise subsequent acclimatization, as described in the next section.

\section{Effect of agar on the ex vitro acclimatization of micropropagated plants}

During the first acclimatization stage, the plants were not affected by the addition of agar to the in vitro nutritive medium, and therefore, generally responded well to the conditions of the first acclimatization stage (Figure 2A). On the other hand, during the second acclimatization stage, agar affected the plants, and the standard concentration ( $\left.7 \mathrm{~g} \cdot \mathrm{L}^{-1}\right)$ interfered with nutrient availability and, as a result, affected plant survival and the differentiation of foliar primordia (Table 2).

However, it is worth mentioning that even though the survival rate of the third acclimatization stage was lower than that of the two previous stages, it was still relatively high, considering that the plants had survived 49 $\mathrm{d}$ of ex vitro acclimatization, 28 of which took place under greenhouse conditions. In a previous study conducted by our research group, the ex vitro acclimatization of micropropagated $H$. chrysotrichus plants was unsatisfactory (data not published), in that the plants had poorly formed root systems, with insufficient quantities of both secondary roots and absorbent hairs. In Malus pumila (apple), Vieira et al. (2007) achieved a mean ex vitro survival rate of $93.5 \%$ for plants micropropagated in a nutritive medium that included vermiculite and vegetal ashes, after $40 \mathrm{~d}$ of growth under greenhouse conditions.

Furthermore, we observed that the rate of growth (i.e., height increase) gradually increased throughout the acclimatization periods. Taken together, the results indicate that the plants were already well acclimatized after $49 \mathrm{~d}$, since they seemed to have resumed growth and development in the ex vitro environment. In addition, it is also likely that the results indicate the efficiency of 
in vitro rhizogenesis, which promoted the formation of adequate root systems that were capable of providing the plants with the required nutrients for ex vitro cultivation.

This result supports the hypothesis that agar reduces the availability of nutrients to the plants, and the higher number of leaves produced during this stage likely contributed to the adaptation process, considering their importance for photosynthesis (HARTMANN et al., 20II). Moreover, the rooting obtained with the lack of plant growth regulators and without interference in plant survival during acclimatization represents a cost reduction in the micropropagation process (GOLLO et al., 2016), with great perspectives to commercial applications.

\section{CONCLUSIONS}

In the present study, we found that the use of $1 / 2$ WPM supplemented with vermiculite, instead of agar, resulted in high mean rates of in vitro rhizogenesis and plants that were capable of initiating acclimatization; however, the inclusion of agar failed to affect the ex vitro acclimatization process, as indicated by the high survival rate and resumed growth and development of the $H$. chrysotrichus micropropagated plants after $28 \mathrm{~d}$ in the greenhouse.

\section{ACKNOWLEDGEMENTS}

Research funded by the Coordenação de Aperfeiçoamento de Pessoal de Nível Superior (CAPES).

\section{REFERENCES}

AGGARWAL, S.; NIRMALA, C. Utilization of coir fibers as an eco-friendly substitute for costly gelling agents for in vitro orchid seed germination. Scientia Horticulturae, v. I33, n. I, p. 89-92, 2012.

ANTONIAZZI, A.P.; BINOTTO, B.; NEUMANN, G.M.; SAUSEN, T.L.; BUDKE, J.C. Eficiência de recipientes no desenvolvimento de mudas de Cedrela fissilis Vell. (Meliaceae). Revista Brasileira de Biociências, v. II, n. 3, p. 3|3-317, 2013.

BRAGA, F.T; PASQUAL, M.; CASTRO, E.M.; RAFAEL, G.C. Características morfofisiológicas de abacaxizeiro 'gomo de mel' enraizado in vitro sob luz natural e substrato vermiculita. Revista Brasileira Fruticultura, v. 33, n. 2, p. 55I-557, 20 II.

CALDAS, L.S.; HARIDASAN, P.; FERREIRA, M.E. Meios nutritivos. In: TORRES, A.C.; CALDAS, L.S. (ed.). Técnicas e aplicações da cultura de tecidos de plantas. Abctp/ Embrapa CNPH, 1990. p. 340-345.
CARGNELUTTI FILHO, A., STORCK, L., TOEBE, M., BURIN, C., ALVES, B. M., FACCO, G. E NEU, I. M. M. Precisão experimental relacionada a tamanhos de parcelas, números de tratamentos e repetições em nabo forrageiro. Pesquisa Agropecuária Brasileira, v.49, n.6, p.428-439, 2014.

CASANOVA, E.; MOYSSET, L.; TRILLAS, M.I. Effect of agar concentration and vessel closure on the organogenesis and hyperhydricity of adventitious carnation shoots, Biologia Plantarum 52: I-8, 2008.

CURTI, A.R.; REINIGER, L.R.S. Formação in vitro de raízes em canafístula: o efeito de diferentes meios de cultivo. Ciência Rural, v. 44, n. 2, p. 3|4-320, 2014.

DAMIANI, C.R.; SCHUCH, M.W. Diferentes substratos e ambientes no enraizamento in vitro de mirtilo. Ciência Rural, v. 39, n. 2, p. 563-566, 2009.

FERREIRA, D.F. Sisvar: a computer statistical analysis system. Ciência e Agrotecnologia, v. 35, n. 6, p. 1039-1042, 201 I.

GALDIANO JUNIOR, R.F.; MANTOVANI, C.; LEMOS, E.G.M. Seleção de agentes alternativos ao ágar para propagação de plântulas de Cattleya loddigesii Lindley (Orchidaceae). Revista Brasileira de Ciências Agrárias, v. 7, suplemento, p. 756-760, 2012.

GOLLO, A.L.; SILVA, A.L.L.; LIMA, K.K.D.; COSTA, J.L.; CAMARA, M.C.; BIASI, L.A.; RODRIGUES, C.; VANDENBERGHE, L.P.S.; SOCCOL, V.T.; SOCCOL, C.R. Developing a plant culture medium composed of vinasse originating from Haematococcus pluvialis culture. Pakistan Journal of Botany, v. 48, n. I, p. 295- 303, 2016.

HARTMANN, H.T.; KESTER, D.E.; DAVIES, F.T.; GENEVE, R. Plant propagation: principles and practices. 8 ed. Englewood Clipps, 20I I. 900p.

KAÇAR, Y.A.; BIÇEN, B.; VAROL, I.; MENDI, Y.Y.; SERÇE, S.; CETINER, S. Gelling agents and culture vessels affect in vitro multiplication of banana plantlets. Genetics and Molecular Research 9 (I): 416-424, 2010.

LORENZI, H. Árvores brasileiras: manual de identificação e cultivo de plantas arbóreas nativas do Brasil. 5 ed. Instituto Plantarum, v. I, 2008. 384p.

LLOYD, G.; McCOWN, B. Commercially feasible micropropagation of montaim laurel, Kalmia latifolia, by use of shoot tip culture. Combined Proceedings of the International Plant Propagators Society, n. 30, p. 42I427, 1981 .

MURASHIGE, T.; SKOOG, F. A revised medium for rapid growth and bio-assays with tobacco tissue cultures. Physiologia Plantarum, v. I5, n. I, p. 437-496, 1962.

OLIVEIRA, A.K.M.; SCHELEDER, E.J.D.; FAVORO, S. Caracterização morfológica, viabilidade e vigor de sementes de Tabebuia chrysotricha (Mart. ex.DC.) Standl. Revista Árvore, v. 32, n. 6, p. I0I I-1018, 2008. 
OLIVEIRA, L.M.; CARVALHO, M.L.M.; SILVA, T.T.A.; BORGES, D.I. Temperatura e regime de luz na germinação de sementes de Tabebuia impetiginosa (Martius ex A. P. de Candolle) Standley e T. serratifolia Vahl Nich. - Bignoniaceae. Ciência e Agrotecnologia, v. 29, n. 3, p. 642-648, 2005.

ROCHA, P.S.G.; FACHINELLO, J.C.; SCHUCH, M.W.; BIANCHI, V.J.; CAMPOS, R.V. Efeito do ágar, vermiculita e sacarose no enraizamento do porta-enxerto cv. Mr. S. 2/5 in vitro. Revista Cientifica Rural, v. I I, n. I, p. 54-59, 2006.

SADEGHI, F; YADOLLAHI, M.; JAFARKHANI KERMANI, M.; EFTEKHARI, M. Optimizing culture media for in vitro proliferation and rooting of Tetra (Prunus empyrean 3) rootstock. Journal of Genetic Engineering and Biotechnology, v. 13, n. I, p. 19-23, 2015.

SCHEIDT, G.N.; SILVA, A.L.L.; OLIVEIRA, Y.; COSTA, J.L.; BIASI, L.A.; SOCCOL, C.R. In vitro growth of Melaleuca alternifolia Cheel in bioreactor of immersion by bubbles. Pakistan Journal of Botany, v. 43, n. 6, p. 2937-2939, 201 I.

SILVA, A.L.L.; COSTA, J.L.; GOLLO, A.L.; SANTOS, J.D.; FORNECK, H.R.; BIASI, L.A.; SOCCOL, V.T.; CARVALHO, J.C.; SOCCOL, C.R.. Development of a vinasse culture medium for plant tissue culture. Pakistan Journal of Botany, v. 46, n. 6, p. 2195-2202, 2014.
SOUZA, A.V.V.; OLIVEIRA, F.J.V.; BERTONI, B.W.; FRANÇA, S.C.; PEREIRA, A.M.S. Enraizamento in vitro de catuaba (Anemopaegma arvense (Vell.) Stell. ex de Souza), uma planta medicinal do Cerrado. Revista Brasileira de Plantas Medicinais, v. 17, n. I, p. 5I-58, 2015.

SUTHAR, R.K.; HABIB, N.; PUROHIT, S.D. Influence of agar concentration and liquid medium on in vitro propagation of Boswellia serrata Roxb. Indian Journal of Biotechnology, v. 10, p. 224-227, 201 I.

VIAGANÓ, R.C.; BIANCHI, V.J.; ROCHA, P.S.G.; SCHUCH, M.W.; FACHINELLO, J.C. Enraizamento in vitro do porta-enxerto de Prunus cv. Mr. S. I/8: concentrações de IBA em meio de cultura acrescido de ágar ou vermiculita. Bioscience Journal, v. 23, n. 3, p. 60-65, 2007.

VIEIRA, R.L.; LEITE, G.B.; WAMSER, A.F. Efeito de substratos porosos no enraizamento in vitro do porta-enxerto de macieira M-9 (Malus pumilla). Revista Brasileira de Fruticultura, v. 29, n. I, p. I28-I32, 2007.

XAVIER, A.; WENDLING, I.; SILVA, R.L. Silvicultura Clonal: Princípios e Técnicas. 2. ED., VER. E AMPL. - Viçosa, MG: Ed. UFV, 20I3. 279 p. 
